\title{
Studi Ekonomi Korupsi di Beberapa Kota di Indonesia Jurnal Ecces
}

\author{
Angga Erlando \\ Program Studi Ekonomi Pembangunan \\ Fakultas Ekonomi dan Bisnis Universitas Airlangga \\ Jl. Airlangga No.4, Airlangga, Kec. Gubeng, Kota SBY, Jawa Timur 60286 \\ E-mail: angga.erlando@feb.unair.ac.id
}

\section{Abstrak: Studi Ekonomi Korupsi Beberapa Kota di Indonesia}

Persoalan korupsi nampaknya ikut memicu masalah-masalah ekonomi dan sosial, menurunkan pertumbuhan ekonomi, mengurangi minat berinvestasi, menghambat distribusi pendapatan, meningkatkan kemiskinan hingga memicu terjadinya inflasi, bahkan korupsi juga diyakini menghambat perbaikan sistem politik. Hasil penelusuran terhadap studi literatur menunjukkan bahwa penelitian berkaitan dengan determinan faktor korupsi terbagi atas tiga jenis tema besar. Hal tersebut meliputi dari perspektif ekonomi, politik, serta sosial dan budaya yang berfokus pada sampel observasi lintas negara di dunia. Sementara itu, penelitian ini berfokus pada studi ekonomi korupsi dengan mempertimbangkan faktor ekonomi seperti pertumbuhan riil, IPM, belanja pemerintah, inflasi, tingkat pengangguran terbuka, dan penerimaan pajak, yang ditengarai berdampak pada tingkat korupsi di skala wilayah yang lebih kecil yaitu daerah perkotaan. Walaupun studi ini masih cukup terbatas, karena data yang tersedia di Indonesia hanya menghasilkan formasi data panel sebanyak 56 obeservasi (14 Kota di Indonesia pada tahun 2004, 2006, 2008, dan 2010). Namun, output penelitian ini memberikan hasil yang menarik. Regresi menggunakan model Tobit yang dilakukan, menunjukkan bahwa faktor ekonomi seperti pertumbuhan riil, belanja pemerintah, dan tingkat pengangguran terbuka memiliki kecenderungan dalam menaikan tingkat korupsi, yang diukur melalui Indeks Perspesi Korupsi (IPK). Sementara itu, variabel IPM berkecenderungan memberikan determinasi menurunkan tingkat korupsi, sedangkan inflasi dan penerimaan pajak daerah bukan merupakan determinan terhadap korupsi. Arah implikasi penelitian ini adalah mendukung hadirnya survei berkaitan dengan tingkat korupsi pada level daerah (kabupaten/kota) secara berkala dan konsiten, serta akselerasi lembaga pencegahan korupsi yang seharusnya ada di setiap daerah.

Kata Kunci: Faktor Ekonomi, Tingkat Korupsi (IPK), Tobit, Beberapa Kota di Indonesia. 


\section{Abstract: Study of Economics Corruption In Some Cities Of Indonesia}

The problem of corruption seems to have contributed to economic and social problems, reduced economic growth, reduced investment interest, inhibited the distribution of income, increased poverty and triggered inflation, and even corruption is also believed to hamper the improvement of the political system. Our literature study shows that research related to the determinants of corruption divided into three types of significant themes, includes an economic, political, and social and cultural perspective. Most of study focuses on observational samples across countries in the world. This study focuses on economics corruption economy by considering economic factors such as real growth, Human Developmen Index (HDI), government spending, inflation, open unemployment rates, and tax revenues, which suspected of having an impact on corruption levels on a smaller scale, such as cities. Although this study is still quite limited, because the data available in Indonesia only resulted in the formation of 56 observation panels data (14 cities in Indonesia in 2004, 2006, 2008, and 2010). However, the output of this study provides interesting results. Regression using the Tobit model shows that economic factors such as real growth, government spending, and the level of open unemployment tend to increase the level of corruption as measured through the Corruption Perspession Index (CPI). Meanwhile, the HDI variable tends to provide a determination to reduce the level of corruption, while inflation and local tax revenue are not determinants of crime. The direction of the implications of this research is to support the presence of surveys related to the level of corruption at the regional (district/city) level regularly and to be consistent, and accelerating of corruption prevention institutions is to be necessary in local level.

Keywords: Economics factors, Corruption Perspession Index (CPI), Tobit Model, Some Cities of Indonesia.

\section{PENDAHULUAN / INTRODUCTION}

Begitu menariknya tema korupsi untuk penelitian dalam studi ekonomika, hal ini membuat banyak ekonom saling adu argumen dan memperdebatkan akibat-akibat korupsi dalam perekonomian. Perdebatan yang dimaksud adalah dua pandangan hipotesis berupa Grease the Wheels Hypothesis (GWH) dan Sand the Wheels Hypothesis (SWH) (Pradiptyo, et al., 2015). Pemahaman terhadap GWH memiliki filosofi menarik di dalamnya, bahwa korupsi ibarat pelumas yang nantinya dapat mempercepat dan memperlancar perekonomian, saat oknum-oknum tertentu mengakali tuntuan birokrasi, aturan, dan keharusan mengikuti prosedur yang berlaku. Keadaan ini dianggap dapat memberikan efisiensi dan efektivitas yang berujung pada lancar dan cepatnya perekonomian (Egger dan Winner, 2005; Sena dan Martinova, 2008; Gazda, 2010, Meon, 2010; Dreher dan Gassebner, 2011). Sementara itu, SWH justru memberikan pandangan yang sebaliknya. Filosofi yang terkandung dalam hipotesis ini adalah ibarat pasir yang saat berjalan menggunakan 
kendaraan bermotor di atasnya, maka perputaran ban menjadi lambat atau bahkan tidak bisa melaju. Hal ini berarti korupsi memberikan dampak buruk/negatif/memperlambat bagi perekonomian (Mauro, 1995, Tanzi, 1998; Bowles, 2000; Jain, 2001; Chang, 2013).

Sungguhpun demikian, Henderson dan Kuncoro (2006), Rivayani (2008), dan Pradiptyo et al. (2015) menganggap bahwa untuk mengasumsikan GWH dapat terjadi di Indonesia adalah sulit diterima, jadi bisa dikatakan GWH tidak berlaku di Indonesia untuk saat ini. Secara lebih lugas Pradiptyo et al. (2015) meyakini peran korupsi dalam GWH dibatasi hanya dalam bidang ekonomi, serta kelancaran birokrasi dalam GWH lebih condong pada keuntungan individu/kelompok berpendapatan menengah ke atas.

Berpedoman pada perdebatan GWH dan SWH, penelitian tentang pengaruh korupsi terhadap variabel lain sepertinya telah banyak dilakukan. Bahkan studi dan peninjauan terhadap literatur memperlihatkan bahwa terhitung sejak akhir abad 20 hingga memasuki awal abad 21, studi dan penelitian "ekonomi-korupsi" banyak mengungkap dampak korupsi terhadap variabel-variabel ekonomi. Seperti halnya pengaruh negatif korupsi terhadap pertumbuhan Gross Domestic Product (GDP) riil (Mauro, 1995; Leite dan Weidman, 1999; Tanzi dan Davoodi, 2000; Abed dan Davoodi, 2000). Kemudian pengaruh korupsi yang negatif terhadap belanja pemerintah (Mauro, 1995), ada pula yang mempengaruhi berkurangnya penerimaan pemerintah (Ghura, 1998; Tanzi dan Davoodi, 2000).

Tidak hanya demikian, korupsi juga diyakini memicu masalah-masalah ekonomi dan sosial lain diantaranya: menurunkan pertumbuhan ekonomi (Mauro, 1995; Knack dan Keefer, 1995; Ehrlich dan Lui, 1999), mengurangi minat berinvestasi (Henisz, 2000; Wei, 2000; Wei dan Javorcik, 2002), menghambat distribusi pendapatan dan meningkatkan kemiskinan (Husted, 1999), dan memicu terjadinya inflasi Al-Mahrubi (2000). Korupsi juga diyakini menghambat perbaikan sistem politik Anderson dan Tverdova (2003), menambah indeks kasus kriminalitas (Azfar dan Gurgur, 2008), serta masih banyak lagi yang lain.

Tren penelitian berkaitan dengan mencari fakta sebab korupsi juga terus berkembang. Artinya cakupan penelitian tidak hanya fokus berkaitan dengan dampak korupsi saja, namun juga lebih spesifik mengarah pada kegiatan mencari tahu determinan yang menyebabkan korupsi dapat terjadi. Setelah meninjau pada hasil review berbagai literatur, banyak disebutkan bahwa korupsi dapat disebabkan oleh banyak determinan. Pellegrini dan Gerlagh (2008), Billger dan Goel (2009), Ata dan Arvas (2011), Agbiboa (2011), Aggrey (2012), Elbahnasawy dan Revier (2012), Dong dan Torgler (2013), 
Erlando, Studi Ekonomi Korupsi di Beberapa Kota di Indonesia.

memaparkan bahwa secara garis besar ada tiga faktor utama pendorong korupsi, antara lain: (1) faktor ekonomi; (2) faktor politik; dan (3) faktor sosial dan budaya. Pada konteks ini, faktor ekonomi bisa menjadi topik favorit yang diteliti oleh para ahli dan ekonom. Selain karena dapat dihubungkan dengan berbagai data ekonomi, para ekonom dapat mengamati lebih dalam faktor laten korupsi yang dilihat dari strategi kebijakan ekonomi.

Merespon realita tersebut, penelitian untuk menganalisis variabel yang merupakan determinan terhadap kasus korupsi di daerah (regional) khususnya dari sudut pandang ekonomi menjadi tujuan penelitian ini. Selama ini banyak penelitian hanya berfokus pada studi kasus lintas negara (Triesman, 2000; Ali dan Isse, 2003; Ata dan Arvas, 2011; Salih, 2013; Cimpoeru dan Cimpoeru, 2015). Bisa dikatakan spesifikasi penelitian lintas daerah (kota/kabupaten) belum banyak dilakukan. Kesempatan untuk melihat variabel ekonomi yang merupakan determinan terhadap korupsi di beberapa Kota Indonesia bisa diambil dengan memanfaatkan data IPK beberapa Kota yang telah disurvei Transparency International Indonesia (TII). Namun IPK yang dipublikasikan pada tahun 2004, 2006, 2008, 2010, dan 2015 tersebut setiap tahunnya ada perbedaan jumlah Kota dan atau Kota tujuan yang menjadi target survei. Walau demikian memilah Kota yang disurvei tahun 2004, 2006, 2008, 2010 sebanyak 14 Kota masih bisa dilakukan agar nantinya menghasilkan data panel.

\section{TINJAUAN TEORITIK / LITERATURE REVIEW}

Definisi korupsi secara harafiah dapat dilihat dari kata "korupsi" yang asalnya dari bahasa Latin "corruptio" Fockeman (1951 dalam Kemendikbud, 2011: 23). Asal kata "corruptio" berasal dari kata bahasa latin yang lebih tua yaitu "corrumpere" yang berarti secara harafiah kebusukan, buruk, ketidakjujuran, penyimpangan dari kesucian. Bahasa latin tersebut di Inggris dikenal dengan istilah "corruption, corrupt", sementara itu di Belanda bernama "corruptie atau korruptie" dengan esensi makna yang juga sama.

Sudut pandang yang dibangun dalam penelitian ini adalah dengan melihat kecenderungan variabel ekonomi dalam menentukan variabel tingakt korupsi dalam bentuk Indeks Persepsi Korupsoi (IPK). Salah satu yang menjadi indikator utama menilai kondisi ekonomi biasanya menggunakan capaian pertumbuhan ekonomi riil (berdasarkan harga konstan). Pertumbuhan ekonomi biasanya memiliki tren dinamis, dan menjadi suatu indikator perekonomian. Hasil review literatur memperlihatkan pertumbuhan termasuk variabel yang dipertimbangkan peneliti sebelumnya dalam melihat apakah pertumbuhan riil merupakan determinan terhadap korupsi pada suatu negara (Ali dan Isse, 2003; Nwabuzor, 
2005; Rehman dan Naveed, 2006; Pellegrini dan Gerlagh, 2008; Ata dan Arvas, 2011; Agbiboa, 2012).

Selanjutnya dalam melihat kondisi tingkat korupsi, juga terdapat studi lain yang juga mempertimbangkan kondisi masyarakat yang tercermin dari kualitas manusianya. Berbeda dengan pandangan sebelumnya, hal ini dapat dilihat dari nilai Indeks Pembangunan Manusia (IPM)/Human Development Index (HDI). Variabel ini banyak digunakan karena di dalamnya mencakup tiga komponen dasar yang merefleksikan upaya pembangunan manusia, yaitu peluang hidup (longevity), pengetahuan (knowledge), dan standar hidup layak (living standards). Fakta empiris memperlihatkan negara maju dengan sumber daya manusia yang unggul, memiliki IPK yang tinggi (Svensson, 2005; Akçay, 2006; Ticky, 2010; Franciari dan Sugianto, 2010, Dridi, 2013), artinya memiliki tingkat korupsi yang rendah.

Menelusuri lebih jauh, banyak aktor koruptor datang dari kalangan elit pemerintah dalam era desentralisasi saat ini. Umumnya mereka melakukan tindak korupsi dengan melakukan penyalahgunaan wewenang terkait alokasi anggaran. Oleh sebab itu variabel seperti belanja pemerintah (government expenditure), biasanya dipertimbangkan masuk ke dalam variabel independen yang dianggap mampu memberikan determinasi terhadap kenaikan tingkat korupsi. Variabel semacam ini berkaitan erat dengan pengelolaan, penggunaan, dan realisasi anggaran yang sepenuhnya tidak bisa lepas dari campur tangan pemerintah. Titik inilah yang biasanya memberikan kesempatan melakukan korupsi, terlebih lagi konteks desentralisasi di Indonesia berdampak pada adanya bantuan anggaran seperti Dana Alokasi Umum (DAU) ataupun Dana Alokasi Khusus (DAU). Review terhadap penelitian empiris yang dilakukan memperlihatkan bahwa variabel belanja pemerintah juga digunakan dalam melihat faktor determinan terhadap korupsi (Del Monte dan Papagni, 2001; Ali dan Isse, 2003; Rock dan Bonnet, 2004).

Dinamisasi perekonomian dapat ditengarai oleh suatu keadaan inflasi yang santa volatil. Variabel ini juga dipertimbangkan oleh banyak peneliti sebelumnya, sebagai faktor yang menjadi determinan terhadap korupsi (Al-Marhubi, 2000; Paldam, 2002; Braun dan DiTella; 2004; Ata dan Arvas, 2011). Inflasi kerap diyakini sebagai senjata jitu melakukan "moral hazard" yang memungkinkan untuk dilakukan oleh oknum koruptor (Paldam, 2002). Inflasi juga dapat dikaitkan dengan kesempatan oknum (pemerintah) melakukan alasan mark-up anggaran, penggelapan, dan lainnya, dengan alasan adanya inflasi (harga diasumsikan naik). 
Logika perilaku yang korup juga berkaitan dengan kondisi perekonomian pada setiap manusia di dalam masyarakat misalnya seperti pengangguran. Saha dan Gounder (2008) mempercayai bahwa ada hubungan antara pengangguran dan korupsi. Sementara itu Kristiansen and Ramli (2006) mengungkapkan bahwa pengangguran telah meningkatkan kasus penyuapan dalam praktek rekruitkmen pegawai negeri sipil di Indonesia. Beberapa peneliti sebelumnya (Rehman dan Naveed, 2007; Bayar, 2011) juga menggunakan variabel pengangguran untuk melihat faktor determinan korupsi.

Variabel terakhir yang tidak kalah penting adalah penerimaan pajak daerah. Penelitian empiris telah dilakukan oleh Rehman dan Naveed (2006) yang menggunakan penerimaan pajak sebagai salah satu variabel untuk melihat determinan korupsi. Lui dan Feng (2015) juga telah menggunakan variabel ini untuk melihat bahwa pajak berpotensi menimbulkan banyak suap dalam proses penghindaran atau penggelapan pajak. Peneliti lainnya (Picur dan Belkaoui, 2006; Cule dan Fulton, 2009; Mandescu; 2011; Rahmani dan Fallahi, 2012; Litina dan Palivos, 2015) juga telah menganggap bahwa antara korupsi dan pajak di dalamnya dianggap ada fenomena yang saling berdampingan dan berkait.

\section{METODE PENELITIAN / METHODS}

\section{Desain Penelitian}

Penelitian ini memiliki bentuk paradigma penelitian kuantitatif-positivistik. Sugiyono (2012) menganggap penelian kuantitatif dimaknai sebagai metode penelitian dengan landasan filsafat positifisme, dengan maksud meneliti pada populasi atau sampel tertentu. Fokus positivisme melahirkan pendekatan paradigma kuantitatif dalam penelitian sosial.

Data indeks persepsi korupsi menjadi variabel dependen dengan nilai 0 hingga 10. Sementara untuk variabel independen, diantaranya: pertumbuhan ekonomi (GRO) dalam satuan persen berdasarkan harga konstan, indeks pembangunan manusia (HDI), belanja pemerintah dalam satuan milyar yang ditransformasi ke dalam bentuk log natural (LNGEX), inflasi (INF) dalam satuan persen, Tingkat Pengangguran Terbuka (TPT) dalam satuan persen, (UNE) Tingkat Pengangguran Terbuka dalam satuan persen, (UNE) penerimaan pajak di daerah dalam satuan milyar yang juga ditransformasi ke dalam bentuk log natural (LNTAX).

Data yang diperoleh merupakan data sekunder yang diperoleh dari dokumen maupun publikasi lembaga/institusi terkait yang relevan dengan penelitian ini. Data Indeks Persepsi Korupsi (14 kota yang terdiri dari Kota Balikpapan, Banjarmasin, Makassar, 
Manado, Denpasar, Surabaya, Semarang, Yogya, Cilegon, Padang, Palembang, Pekanbaru, Batam, dan Medan tahun 2004, 2006, 2008, 2010) diperoleh dari Komisi Pemberantasan Korupsi (KPK) dan Transparency Indonesia. Sementara data pertumbuhan riil, IPM, belanja pemerintah, inflasi, pajak daerah diperoleh peneliti dari dokumen-dokumen yang dipublikasikan oleh Badan Pusat Statistik (BPS) dalam bentuk softcopy. Selanjutnya data pengangguran terbuka, diperoleh dari berbagai sumber skunder (laman website pemerintah di setiap kota yang menjadi sampel, dan berbagai sumber yang publikasinya parsial).

Formasi tersebut, dianggap sebagai pemanfaatan data dependen terbaik dengan jumlah sampel (n) terbanyak yaitu 56 (data dependen ketersediannya terbatas). Sebab, survei IPK pada tahun 2004 hanya 21 kota, tahun 2006 (32 kota), tahun 2008 (50 kota), dan tahun 2010 (50 kota), namun sistem pemilihan sampelnya kurang konsisten. Artinya, kota yang disurvei tidaklah sama (tempat dan jumlahnya) pada rentang periode 4 tahun tersebut, walaupun ada beberapa kota yang selalu disurvei. Semua data yang terkumpul peneliti input ke dalam program Microsoft Excel 2010 sebagai bahan untuk diolah dalam eviews 11.0 .

\section{Metode Analisis Data}

Metode analisis yang digunakan dalam penelitian ini adalah dengan menggunakan analisis regresi model Tobit. Regresi model Tobit digunakan mengingat variabel dependen yaitu korupsi diukur menggunakan IPK yang bersifat laten dan kualitatif, serta nilainya terbatas yaitu dari 0-10 (skala yang dibatasi). Alasan lain pemelihan menggunakan Tobit, selain variabel dependen yang bersifat kualitatif dan terbatas nilainya (0-10), penggunaan teknik analisis regresi Tobit ini juga didukung oleh penelitian sebelumnya. Penelitian tersebut dilakukan oleh Ata dan Arvas (2011) yang mencoba meneliti determinan ekonomi korupsi di 25 negara Eropa (2004-2007) menggunakan regresi Tobit, dengan pendekatan data rata-rata. Selain itu hal ini berkaitan dengan keterbatasan data, sebab data IPK di beberapa kota Indonesia hanya terjadi 5 kali dengan sampel yang berubah tidak konsisten.

Sementara itu, penggunaan periode dua tahunan dilakukan karena pernah ada yang melakukan penelitian dengan rentang waktu yang kurang lebih sama, yaitu penelitian oleh Cimpoeru dan Cimpoeru (2015) dengan judul Budgetary Transparency-an Improving Factor for Corruption Control and Economic Performance. Datanya bisa dikatakan berbentuk panel periode dua tahunan yaitu pada tahun 2006, 2008, 2010, 2012 pada negara-negara yang 
masuk kedalam survei OBI (Open Budgetary Transparency) sebanyak 59 negara. Sementara itu analisisnya menggunkan metode PLS (Pooled Least Squares) yang dipilih terdiri dari variabel independen: transparansi anggaran (OBI), dan GDP per kapita.

\section{Regresi Menggunakan Model Tobit}

Pengembangan dari model Probit dikembangkan oleh James Tobin (1958) menjadi Tobit (Tobit Mode/). Sampel data variabel dependennya hanya ada untuk sebagian dari sampelnya, dan biasa disebutl sebagai sampel tersensor (censored sample). Sampel tersensor tersebut dibedakan dengan sampel terpotong (truncated sample) yaitu informasi tentang variabel independen hanya ada jika variabel dependen terobservasi. Regresi model Tobit dianggap sebagai model regresi dengan variabel dependen terbatas (limited dependent variable regression models), karena restriksi yang ada pada variabel dependen (Gujarati dan Porter, 2012). Secara matematis Gujarati dan Porter (2012) memformulasikan regresi model Tobit dapat dituliskan:

$$
\begin{aligned}
& Y_{i}=a+\beta X_{i}+\varepsilon_{i} \quad \text { jika RHS }>0 \\
& =0 \quad \text { jika sebaliknya }
\end{aligned}
$$

Dimaknai bahwa RHS = sisi sebelah kanan (right-hand side). Variabel X (independen) dapat saja diberikan atau ditambahkan pada model. Berkaitan dengan persamaan matematis tersebut, maka model fungsi indeks persepsi korupsi di beberapa kota di Indonesia dinyatakan dinyatakan dalam persamaan:

$$
C P I=a+\beta 1 G R O+\beta 2 \text { HDI }+\beta 3 \text { LNGEX }+\beta 4 \text { INF }+\beta 5 \text { UNE }+\beta 6 \text { LNTAX }+\varepsilon
$$

Keterangan:

$\begin{array}{ll}\text { CPI } & : \text { Indeks Persepsi Korupsi (IPK), (0-10) } \\ \text { GRO } & : \text { Pertumbuhan Rill (persen) } \\ \text { HDI } & : \text { Indeks Pembangunan Manusia (0-100) } \\ \text { LNGEX } & : \text { Log Natura/ dari belanja riil Pemerintah Kota (rupiah) } \\ \text { INF } & : \text { Inflasi (persen) } \\ \text { UNEM } & : \text { Tingkat Pengangguran Terbuka (persen) } \\ \text { LNTAX } & : \text { Log natura/ dari penerimaan pajak riil daerah (rupiah) } \\ a & : \text { Konstanta/Intercept } \\ \beta 1, \beta 2, \beta 3, \beta 4, \beta 5, \beta 6: \text { Koefisien Regresi } \\ \varepsilon\end{array}$




\section{HASIL DAN PEMBAHASAN / DISCUSSION}

Berdasarkan tabel yang ada, menunjukkan hasil estimasi regresi Tobit dengan interpretasi berikut:

1. Berdasarkan hasil olah data dan perhitungan menggunakan alat bantu Eviews 11.0. Dapat dilihat bahwa hasil $p$-value pada variabel pertumbuhan ekonomi $(G R O)=$ 0.0070, indeks pembangunan manusia $(\mathrm{HDI})=0.0056$, belanja pemerintah $(L N G E X)=0,0284$, dan pengangguran $(U N E)=0,0038$ memiliki tanda signifikan yang berkencederungan dapat mempengaruhi variabel korupsi pada tingkat kesalahan estimasi 5 persen. Sementara itu, variabel inflasi $(I N F)=(0,1025)$ dan penerimaan pajak daerah $($ LNTAX $)=0.7849$ tidak signifikan, sehingga tidak berkecenderungan mempengaruhi variabel korupsi pada tingkat kesalahan estimasi 5 persen.

2. Nilai kofisien masing-masing variabel independen dalam penelitian menggunakan regresi model Tobit ini, mengandung 2 (dua) sifat mutlak yaitu "merupakan determinan yang positif $(+)^{\prime \prime}$ dan merupakan determinan yang bersifat negatif $(-)$. Karena variabel dependen korupsi memiliki satuan yang cara membacanya "berbeda" dengan variabel dependen kualitatif kebanyakan (tren IPK mendekati nilai nol artinya korupsi meningkat dan tren mendekati nilai 10 artinya korupsi membaik/bersih dari korupsi). Bila ada variabel independen yang memiliki nilai kofisien negatif (-) dan signifikan dapat dibaca "berkecenderungan mempengaruhi atau determinan yang meningkatkan tingkat korupsi". Sementara untuk variabel independen yang memiliki nilai kofisien positif $(+)$ dan signifikan dibaca "berkecenderungan mempengaruhi atau determinan yang menurunkan tingkat korupsi".

3. Berdasarkan nilai kofisien dan signifikansi variabel independen yang menunjukkan sebagai determinan dalam meningkatkan tingkat korupsi diantaranya: pertumbuhan ekonomi $(G R O)=0.0070$, belanja pemerintah $(L N G E X)=0,0284$, pengangguran $(U N E)=0,0038$, sedangkan indeks pembangunan manusia $(\mathrm{HDI})=0.0056$, justru sebaliknya menujukkan arah kecenderungan sebagai determinan dalam menurunkan tingkat korupsi. Sisanya variabel inlasi (INF)=0,1025 dan penerimaan pajak daerah $($ LNTAX $)=0.7849$ tidak memiliki nilai signifikansi kurang dari 5 persen, dapat dianggap kedua variabel ini bukan merupakan determinan terhadap tingkat korupsi.

4. Perlunya melihat tingkat kebaikan model secara bersama-sama dalam regresi model Tobit, digunakalah Likelihood Ratio (LR). Likelihood Ratio (LR) ini mirip dengan uji F 
pada analisis OLS. Hasil uji LR sebesar 25.36761 dengan nilai $p$-value sebesar 0,0003 yang lebih kecil dari tingkat kesalahan yang diterima sebesar 0.05 . Oleh sebab itu, variabel-variabel independen (pertumbuhan ekonomi, indeks pembangunan manusia, belanja pemerintah, inflasi, pengangguran, dan penerimaan pajak daerah) memiliki kecenderungan sebagai determinan yang secara simultan mendorong korupsi.

\section{Interpretasi Hasil Output}

Tabel 1. Ringkasan Hasil Perhitungan Model Tobit Menggunakan Software Eviews 11.0

\begin{tabular}{lrrr}
\hline \multicolumn{1}{c}{ Variable } & Coefficient & Z-Statistic & \multicolumn{1}{c}{ P-Value } \\
\hline GRO & -0.170639 & -2.698853 & 0.0070 \\
\hline HDI & 0.068133 & 2.770221 & 0.0056 \\
\hline LNGEX & -0.507810 & -2.191735 & 0.0284 \\
\hline INF & 0.061786 & 1.633043 & 0.1025 \\
\hline UNE & -0.064173 & -2.893108 & 0.0038 \\
\hline LNTAX & 0.035517 & 0.272915 & 0.7849 \\
\hline C & 10.23631 & 3.092471 & 0.0020 \\
\hline
\end{tabular}

Likelihood Ratio (Chi-square Statistic) $=25.36761$

Prob. Chi-square $\quad=0.0003$

Sumber: Diringkas dari Hasil Regresi Data Penelitian dalam Eviews 11.0, 2019.

\section{Determinasi Variabel Pertumbuhan Ekonomi terhadap Tingkat Korupsi}

Temuan penelitian ini menunjukkan laju pertumbuhan sebagai variabel independen memiliki kecenderungan memberikan determinasi terhadap naiknya tingkat korupsi. Hasil ini berbeda dengan penelitian Ali dan Isse (2003), Rehman dan Naveed (2006), dan penelitian yang dilakukan Ata dan Arvas (2011) yang menunjukkan tidak ada hubungan, pengaruh, determinasi, ataupun probabilitas variabel pertumbuhan ekonomi dalam menaikan atau menurukan tingkat korupsi yang diukur dengan Indeks Persepsi Korupsi (IPK). Kemungkinan yang terjadi, bisa diakibatkan karena adanya perbedaan karakteristik wilayah yang menjadi sampel dalam penelitian ini (14 Kota) dibanding bila sampelnya adalah sekumpulan negara tertentu. Banyak penelitian yang melihat hubungan pertumbuhan ekonomi dengan korupsi menggunakan analisis data antarnegara, sedangkan dalam penelitian ini sampel yang dilakukan adalah dalam lingkup regional atau beberapa Kota saja.

Namun demikian, berbeda dengan dua penelitian tersebut, Hoa (2010) yang meneliti hubungan antara pertumbuhan ekonomi dan korupsi di 15 negara Asia pada tahun 2001 dan 2008. Hasil penelitiannya menunjukkan bahwa semakin tinggi pertumbuhan dapat mengakibatkan bertambahnya korupsi yang ditandai dengan semakin rendahnya Indeks Persepsi Korupsi (IPK) di 15 negara Asia yang masih berkembang. Penelitian lain yang mendukung hasil penelitian ini adalah yang dilakukan Nugroho (2013), bahwa semakin 
tinggi tingkat pertumbuhan nasional Indonesia (diukur menggunakan PDB atas dasar harga konstan) dapat memberikan dampak semakin tinggi tingkat korupsinya.

Hasil penelitian ini seperti berbenturan dengan fenomena yang umum terjadi di negara maju. Bahwa negara maju di dunia yang memiliki pertumbuhan stabil dan cukup tinggi memiliki indeks persepsi korupsi yang tinggi pula (Seligson, 2002; Aidt dan Duta, 2008; Abramo, 2008; Ticky, 2010; Rose and Mishler, 2010). Bahkan Aidt (2011) meyakini negara dengan pertumbuhan ekonomi tinggi yang masuk sebagai kategori negara maju dianggap lebih memiliki anggaran besar dalam menanggulangi korupsi, serta sistem yang lebih baik dalam mengatasi korupsi. Oleh karena itu, cukup rasional bila di negara berkembang, pertumbuhan ekonomi belum tentu sama peranannya terhadap tingkat korupsi yang terjadi.

\section{Determinasi Variabel IPM terhadap Tingkat Korupsi}

Penelusuran literatur dalam lingkup sampel antarnegara menyebutkan bahwa negara dengan nilai Indeks Pembangunan Manusia (IPM) yang semakin tinggi, memicu tingkat korupsi yang menurun dan tidak hanya ditandai dengan naiknya nilai IPK yang saja. Secara khusus IPM juga pasti dapat mendorong akses kontrol atau penanggulangan korupsi, layanan fasilitas pencegahan dan pemberantasan korupsi, gaya hidup masayarakat, dan lain sebagainya (Akçay, 2006; Touati, 2014). Penelitian ini juga mendukung temuan hasil penelitian Cimpoeru dan Cimpoeru (2015) yang menunjukkan bahwa pendidikan yang baik di negara-negara dunia (negara dalam list Open Budget Index) dapat mengurangi korupsi yang ditandai dengan meningkatnya IPK.

Sejauh melakukan kajian literatur, belum ditemukan hasil penelitian yang menunjukkan bahwa IPM yang naik berkecenderungan menurunkan nilai IPK (meningkatkan tigkat korupsi). Temuan Mohtadi dan Roe (2003, dalam Pradiptyo et al., 2015) juga menunjukkan hasil temuan yang tidak jauh berbeda bahwa hubungan antara korupsi dan demokrasi seperti huruf $U$ terbalik yang menunjukkan terdapat crowding out effect. Maksudnya pada saat awal demokrasi misalnya (dikaitkan dengan reformasi 1998), biaya partisipasi rendah oleh sebab itu terjadi penambahan jumlah rent-seekers yang bisa dikatakan belum terkendali. Selain peluang yang terbuka tersebut, sistem demokrasi terbaik juga belum dibentuk. Sebagai konsekuensinya, pada tahap awal demokrasi tersebut, korupsi cenderung meningkat. 
Fenomena penurunan tingkat korupsi yang terdeterminasi oleh naiknya nilai IPM juga dapat dilihat pada indikator pemerintahan Indonesia. Pada masa berakhirnya Orde Baru, terjadi penurunan aspek kelembagaan di berbagai indikator. Hal serupa terjadi pada periode 1996-2003, ketika itu Indonesia berada dalam kondisi krisis di tahun 1998 dan kemudian terjadi proses pemulihan dari dampak krisis ekonomi tersebut. Hal tersebut tentu sulit terjadi jika kualitas pembangunan manusia yang terjadi di Indonesia tidak berjalan ke arah yang lebih baik

Jika kemudian dikaitkan dengan yang terjadi saat ini kondisi pengendalian yang terbilang sangat masif dilakukan juga tercermin dari adanya pembentukan Komisi Pemberantasan Korupsi (KPK) yang berdiri sejak tahun 2004. Bahkan Lembaga Swadaya Masyarakat (LSM) seperti Indonesia Corruption Watch (ICW), Perempuan Anti Korupsi, Indonesian Corruption Investigation (ICI), dan lebih dari 30 LSM di Indonesia lainnya juga merupakan hasil dari peningkatan kualitas sumber daya manusia Indonesia saat ini. Pada lingkup pendidikan tinggi juga tidak mau kalah karena ada PUKAT (Pusat Kajian Anti Korupsi) UGM, Monitor Korupsi FEB UGM, Pusat Studi Ilmu Hukum dan Anti Korupsi di UNHAS, dan lain sebagianya. Rangkaian penjelasan dan argumen bagaimana faktor ekonomi IPM yang berkecenderungan memberikan determinasi dalam menurunkan tingkat korupsi terlihat secara jelas dari berbagai fenomena yang terjadi di berbagai negara dan Indonesia.

\section{Determinasi Variabel Belanja Pemerintah terhadap Tingkat Korupsi}

Variabel independen belanja pemerintah langsung riil berkecenderungan memberi determinasi terhadap peningkatan tingkat korupsi. Hal tersebut ditandai dengan arah penurunan IPK (koefisien negatif). Artinya penelitian ini cukup sesuai dengan penelitianpenelitian sebelumnya yang melihat belanja pemerintah sebagai faktor ekonomi yang memberikan determinasi terhadap korupsi (Del Monte dan Papagni, 2001; Ali dan Isse, 2003; Rock dan Bonnet, 2004).

Penelitiannya Ali dan Isse (2003) juga selaras dengan hasil dalam penelitian ini. Walupun variabel belanja pemerintah dilihat dari pengeluaran pemerintah yang memiliki kostribusi pada GDP (government size). Negara dengan anggaran besar biasanya memiliki rencana pengeluaran yang besar untuk mendorong pertambahan GDP. Dalam penelitiannya hal tersebut dianggap memiliki potensi dalam meningkatkan korupsi. Sementara itu, secara lebih spesifik temuan Gupta et al. (2001) juga telah memperlihatkan hal yang serupa walaupun variabel belanja pemerintahnya adalah belanja militer pemerintah. Hal serupa juga didukung oleh Agostino et al. (2011), yang menyebutkan bahwa membesarnya 
ukuran/besar pengeluaran pemerintah pada pengeluaran untuk keperluan militer secara kuat dapat mempengaruhi korupsi meningkat.

Kajian lain yang dilakukan Kotera et al. (2012) juga memandang lebih pada pengeluaran pemerintah bukan belanja pemerintah (operasional) yang dianggap memiliki pengaruh positif terhadap korupsi. Walau demikian, penelusuran terhadap literatur penelitian sebelumnya menemukan bahwa penelitian Billger dan Goel (2009) yang menggunakan sampel 100 negara (data cross section) teryata menunjukkan pangeluaran pemerintah (sebagai government size) ternyata sama sekali tidak signifikan dalam mempengaruhi korupsi.

\section{Determinasi Variabel Inflasi terhadap Tingkat Korupsi}

Variabel independen inflasi (INF) tidak signifikan dalam meningkatkan atau menurunkan tingkat korupsi. Hal ini cukup bertolak belakang dengan penelitian sebelumnya (Al-Marhubi, 2000; Paldam, 2002; Braun dan DiTella; 2004; Ata dan Arvas, 2011; Samimi et al., 2012; Akca et al., 2012). Padahal Inflasi kerap diyakini sebagai bentuk tindak "moral hazard" yang bukan hanya diakukan oleh sesorang yang ingin mencairkan asuransiasuransinya (mobil, rumah, kesehatan, dan lainnya), namun pada konteks ini juga berlaku untuk koruptor (oknum swasta dan pemerintah) (Paldam, 2002). Penelitian lain yang bertolak belakang dengan hasil dalam penelitian ini adalah yang dilakukan oleh Braun dan Di Tela (2004) saat melihat determinansi inflasi dalam meningkatkan korupsi pada 75 negara pada tahun 1982-1994. Kemudian, penelitian Tosun (2002) pada 44 negara di dunia yang secara random dipilih pada 1982-1995. Hasilnya menyatakan korupsi berasal dari inflasi yang tinggi. Walaupun terbilang sudah lama, namun penelitian-penelitian tersebut sering menjadi rujukan banyak peneliti hingga saat ini.

Penelitian yang dilakukan oleh Ata (2009) yang mencoba melakukan investigasi berkaitan dengan pengaruh inflasi terhadap korupsi pada 25 negara di Eropa (2004-2007) juga tidak jauh berbeda, artinya inflasi menyebabkan korupsi (inflasi naik, IPK turun yang menunjukkan korupsi semakin parah). Kemudian Getz dan Vokema (2011) juga membuktikan hal serupa walaupun variabel yang digunakan adalah "the economic ambiguity" namun variabel tersebut diambil yang merepresentasikan kenaikan harga barang/jasa secara umum (inflasi). Berdasarkan argumen dan uraian-uraian tersebut, mengkaitkan inflasi dengan korupsi yang terjadi di beberapa Kota Indonesia mungkin 
Erlando, Studi Ekonomi Korupsi di Beberapa Kota di Indonesia.

relevan jika didukung dengan data korupsi tahunan yang lebih banyak. Sebab inflasi seperti yang diungkapakan Getz dan Volkema (2011) sebagai "the economic ambiguity", cukup sulit dibayangkan bila terjadi inflasi lantas sertamerta dapat memicu peningkatan korupsi.

\section{Determinasi Variabel Pengangguran Terbuka terhadap Tingkat Korupsi}

Hasil model regresi Tobit dalam penelitian ini menunjukkan bahwa variabel independen yang kelima, yaitu tingkat pengangguran terbuka secara hasil statistik dapat dikatakan berkecenderungan memberikan determinasi dalam meningkatkan tingkat korupsi. Hasil ini susuai penelitian-penelitian sebelumnya. Misalnya saja dari hasil penelitian yang dilakukan oleh Saha dan Gounder (2008). Temuannya menunjukkan bahwa terdapat kaitan antara pengangguran dan korupsi. Penelitian lain yang juga sependapat adalah hasil temuan Kristiansen dan Ramli (2006). Hasil penelitiannya juga menunjukkan adanya indikasi pengangguran secara rasional memicu peningkatkan kasus penyuapan, khususnya dalam praktek penerimaan pegawai negeri sipil di Indonesia. Beberapa peneliti sebelumnya yang mempertimbangkan dan menggunakan variabel pengangguran sebagai variabel ekonomi untuk melihat determinan korupsi juga telah ada (Rehman dan Naveed, 2007; Nazir et al., 2009; Bayar, 2011).

Hasil penelitian yang menunjukkan gambaran peran pengangguran dalam mendorong korupsi untuk kasus "wilayah kota" bahkan telah dilakukan oleh Nazir et al. (2009). Tulisannya mencoba membuktikan dengan melakukan penelitian berjudul Socioeconomic Impact of Ununemployment in Urban Faisalabad, Pakistan. Setelah melakukan sebar kuisioner dan melakukan wawancara terhadap informan kunci di Kota Faisalabad Pakistan, disimpulkan bahwa sekitar 71 persen responden menyepakati bahwa pengangguran yang terjadi di kota tersebut memicu dan mendorong terjadinya korupsi. Hal itu menciptakan suasana saling tidak percaya, ketidakjujuran, dan meningkatkan jumlah kasus kriminalitas "korupsi" yang banyak mengekspose tokoh-tokoh korupsi di Faisalabad.

Kemudian, sadar atau tidak selama ini opini publik mengarah pada suatu pandangan umum, bahwa pengangguran merupakan fenomena yang terjadi karena disebabkan oleh banyak hal. Namun seiring perkembangan waktu yang menempatkan pengangguran sebagai masalah sosial khususnya di negara-negara berkembang. Pengangguran juga dianggap memberikan banyak dampak-dampak negatif. Bukan hanya masalah standar hidup yang sulit dicapai, namun juga memicu persaingan bisnis yang tidak baik, kemiskinan, tindak kekerasan, peningkatan kriminalitas termasuk didalamnya tindak pidana korupsi (Neeleman and Lewis, 1999; Asghar 2002; Blakely et al., 2003). 
Jika mengkaitkan dengan yang terjadi di beberapa Kota negara Indonesia khususnya seperti sampel yang ada dalam penelitian ini. Hasil penelitian Kristiansen and Ramli (2006) dan Boboc (2009) sepertinya cukup memberikan gambaran argumen yang rasional dan logis. Keduanya sama-sama berpendapat bahwa temuan penelitian yang menunjukkan pengangguran memicu korupsi dapat dilihat dari banyaknya fenomena suap khususnya untuk mendapatkan pekerjaan.

\section{Determinasi Variabel Penerimaan Pajak Daerah terhadap Tingkat Korupsi}

Hasil estimasi regresi menunjukkan bahwa bahwa pajak daerah tidak berpengaruh signifikan. Walaupun cukup berbeda dengan penelitian sebelumnya (Rahmani dan Fallahi, 2012; Antonakas et al., 2013; Litina dan Palivos, 2015; Lui dan Feng, 2015) yang beranggapan bahwa antara korupsi dan pajak di dalamnya terdapat hubungan yang saling terkait, namun sebenarnya bukan berarti pajak daerah tidak memiliki pengaruh secara riil terhadap probabilitas akan terjadinya korupsi. Mengidentifikasi korupsi yang terjadi pada perpajakan bukan merupakan hal yang mudah, terlebih hanya dilihat dari angka saja. Oleh karena itu, perlu dilakukan penelitian lebih lanjut. Hasil estimasi yang berbeda tersebut dapat disebabkan karena nilai pajak daerah masih dalam bentuk agregat yang asalnya dari komponen pajak hotel, pajak restoran, pajak hiburan, pajak reklame, dan sumber pajak daerah yang lain. Tidak menutup kemungkinan apabila salah satu atau beberapa komponen pajak daerah itu diteliti satu per satu secara empiris kemungkinan hasilnya dapat signifikan dalam menjelaskan penyebab korupsi di daerah, utamanya di daerah perkotaan. Oleh sebab itu, penelitian kualitatif dapat menjadi alternatif jika ingin mendalami fenomena seperti ini.

\section{KESIMPULAN / CONCLUSION}

Berdasarkan hasil analisis penelitian menggunakan regresi model Tobit dengan sampel 14 daerah perkotaan Indonesia (2004, 2006, 2008, dan 2010) yang meliputi Balikpapan, Banjarmasin, Makassar, Manado, Denpasar, Surabaya, Semarang, Yogya, Cilegon, Padang, Palembang, Pekanbaru, Batam, dan Medan. Dapat diambil kesimpulan bahwa faktor ekonomi (variabel independen) yang memiliki kecenderungan dalam memberikan determinasi terhadap peningkatan tingkat korupsi adalah pertumbuhan ekonomi riil (GRO), belanja pemerintah (LNGEX), dan tingkat pengangguran terbuka (UNE). Sementara faktor ekonomi IPM sebalikya, karena naiknya nilai IPM akan memberikan 
determinasi terhadap naiknya nilai (IPK). Selanjutnya faktor ekonomi inflasi (INF) dan penerimaan pajak daerah (LNTAX) hasil penelitian secara statistik menunjukkankan kedua variabel tersebut bukan merupakan determinan terhadap tingkat korupsi.

Sebagai saran, sangat diperlukan survei lanjutan berkaitan dengan pembuatan data tingkat korupsi, yang seharusnya tidak hanya di kota saja, namun juga di tingkat kabupaten (menambah jumlah daerah survei). Mengingat, selama ini survei hanya terjadi 5 kali dan dilakukan bukan oleh pemerintah melainkan TII (terjadi pada 2004, 2006, 2008, 2010, dan 2015). Hal ini dapat membawa manfaat sebagai bentuk melihat gambaran korupsi di daerah, keperluan penelitian, dan bahan perumusan kebijakan. Selain itu, diperlukan penelitian lebih lanjut berkaitan dengan analisis determinan faktor ekonomi terhadap tingkat korupsi di daerah perkotaan, dengan metode dan pendekatan penelitian yang lain. Kedua hal tersebut akan semakin baik, bila disandingkan dengan akselerasi lembaga pencegahan korupsi yang seharusnya ada di setiap daerah.

\section{DAFTAR PUSTAKA / REFERENCES}

Abed, G. T. dan Davoodi, H.R. 2000. Corruption, Structural reforms, And Economic Performance In The Transition Economies. IMF Working Paper, No 00/132, July: 141.

Abramo, C. W. 2008. How Much Do Perceptions of Corruption Really Tell Us ?. www.economics-ejournal.org, Vol. 2, No. 1, February: 1-56.

Agbiboa, D.E. 2012. Between Corruption and Development: The Political Economy of State Robbery in Nigeria. Journal of Business Ethics. Vol.108, No. 3, July: 325-345.

Aggrey, Niringiye. 2012. Determinants of Corruption at District Levels in Uganda. International Journal of Economic Perspectives, Vol. 6, No. 4 July: 67-72.

Aidt, T. S. 2011. The Causes Of Corruption. https://www.cesifo-group.de. Diakses Pada Tanggal 22 Oktober 2015.

Aidt, T. S. dan Dutta, J. 2008. Policy Compromises: Corruption And Regulation In A Democracy. Economics and Politics. Vol. 20, No. 3, November: 335-360.

Akça, H., Ata, A. Y., dan Karaca, C. (2012). Inflation and corruption relationship: Evidence from panel data in developed and developing countries. International Journal of Economics and Financial Issues, 2(3), 281-295.

Akcay, Selcuk. 2006. Corruption And Human Development. Cato Journal, Vol. 26, No. 1, Winter: 29-48. 
Ali, M. A. dan Isse, H. S. 2003. Determinants of Economic Corruption: A Cross-Country Comparison. Cato Journal, Vol. 22, No.3, July: 449-466.

Al-Marhubi, Fahim. A. 2000. Corruption and Inflation. Economics Letters, Vol. 66. No. 2, February: 199-202.

Ali, Muhammad. 1993. Kamus Lengkap Bahasa Indonesia Modern. Pustaka Amani. Jakarta Anderson, C.J., dan Tverdova, Y.V. 2003. Corruption, Political Allegiances, and Attitudes Toward Government in Contemporary Democracies, American Journal of Political Science, Vol. 47, No. 1, January: 91-109.

Antonakas, N. P., Giokas, A. E., \& Konstantopoulos, N. 2013. Corruption in Tax Administration: Interviews with Experts. Procedia-Social and Behavioral Sciences, 73, 581-589.1-589.

Asghar Muhammad 2002. Economic Stress: Main Cause of Rising Suicides Cases. Dawn, Vol. 4, No. 5, April: 1-10.

Ata, A.Yilmaz. 2009. Opportunity and Motivation of Corruption in the Framework of Institutional Economics: An Analysis on EU Countries. Economic Research Foundation Publications. Istanbul.

Ata, A. Yilmaz dan Arvas, M. Akif. 2011. Determinants Of Economic Corruption: A CrossCountry Data Analysis. International Journal of Business and Social Science, Vol. 2, No. 13, July: 161-169.

Azfar, O. dan Gurgur, T. 2008. Police Corruption, Crime and Crime Reporting: A Simultaneous Equations Approach. NUPI WorkingPaper, Department of International Economics, No. 743, June: 1-36.

Bayar, Guzin. 2011, Causes Of corruption. Dynamic Panael Data Analysis Of Some Post Soviet Countries And East Asian Countries. The Journal of Applied Business Research, Vol. 27, No. 1, February: 77-86.

Billger, Sherrilyn M. dan Goel, Rajeev K. 2009. Do Existing Corruption Levels Matter In Controlling Corruption ?: Cross-Country Quantile Regression Estimates. Journal of Development Economics, Vol. 90, No. 2, November: 299-305.

Blakely, T. A., Collings, S. C., \& Atkinson, J. 2003. Unemployment and suicide. Evidence for a causal association?. Journal of Epidemiology \& Community Health, 57(8), 594-600.

Boboc, E. 2009. Identifying Determination Of Corruption In Health Care: A Cross-Country Analysis. Thesis in Central European University Department Of Economics. Budapest. 
Erlando, Studi Ekonomi Korupsi di Beberapa Kota di Indonesia.

Bowles, R. 2000. Corruption. in B. Boudewijn and G. De Greest, eds. Encyclopedia of Law and Economics, Vol. 5, The Economics of Crime and Litigation 460-491. Edward Elgar.

Braun, M. dan Di Tella, R. 2004. Inflation, Inflation Variability, and Corruption, Economics \& Politics. Vol.16, No.1, 77-100.

Chang, E. C. C. 2013. A Comparative Analysis of How Corruption Erodes Institutional Trust. Taiwan Journal of Democracy, Vol. 9, No.1, July: 73-92.

Cimpoeru, M. V. Dan Cimpoeru, V. 2015. Budgetary Transparency-An Improving Factor for Corruption Control and Economic Performance Procedia Economics and Finance, Vol. 27, 579-586.

Cule, Monica dan Fulton, Murray. 2009. Business Culture And Tax Evasion: Why Corruption And The Unofficial Economy Can Persist. Journal of Economic Behavior and Organization. Vol. 72, No. 3, December: 811-822.

D’Agostino, G., Dunne, J. P., \& Pieroni, L. (2012). Corruption, military spending and growth. Defence and Peace Economics, 23(6), 591-604.

Del Monte, A. dan E. Papagni. 2001. Public Expenditure, Corruption, and Economic Growth: The Case of Italy. European Journal of Political Economy, Vol. 17, No.1, March: 1-16.

Dong, Bin dan Torgler, B. 2012. Causes of corruption: Evidence from China. China Economic Review, Vol. 26, No. 3 (C), April: 152-169

Dreher, A. dan Gassebner, M., 2011. Greasing the Wheels ? The Impact of Regulations and Corruption on Firm Entry. Journal of Public Choice, Vol.155, No. 3, October: 413-432.

Dridi, Mohamed. 2013. Corruption and Economic Growth: The Transmission Channels. Journal of Business Studies Quarterly, Vol. 4, No. 4, 121-152.

Egger, P. dan Winner, H., 2005. Evidence On Corruption As An Incentive for Foreign Direct Investment. European Journal of Political Economy, Vol.21, No. 4, December: 932952.

Ehrlich dan Lui, 1999. Bureaucratic Corruption and Endogenous Economic Growth. Journal of Political Economy, University of Chicago Press, Vol. 107, No.6, December: 270-293.

Elbahnasawy, Nasr dan Revier, Charles F. 2012. The Determinants of Corruption: CrossCountry-Panel-Data Analysis. The Developing Economies, Vol. 50, No. 4, November: 311-333. 
Franciari, P. S. dam Sugiyanto, FX. 2010. Analisis Hubungan Ipm, Kapasitas Fiskal, Dan Korupsi Terhadap Kemiskinan Di Indonesia (Studi Kasus 38 Kabupaten/Kota Di Indonesia Tahun 2008 dan 2010). Diponegoro Journal Of Economics. Vol.2, No. 2, 114.

Gazda, K., 2010. Does Corruption "Grease the Wheels" of Growth? Empirical Evidence from MENA Countries. Working Paper on Laboratoire d'Economie et de Finance Appliquée (LEFA) - IHEC Carthage.

Getz, K. A. dan Volkema, R. J. 2001, Culture, Perceived Corruption and Economics: Model of Predictors and Outcomes. Business and Society, Vol.40, No.1, 7-30.

Ghura. 1998. Tax Revenue in Sub-Saharan Africa: Effects of Economic Policies and Corruption. IMF Working Paper, No 98/135, September: 1-25.

Gujarati, Damodar dan Porter, Dawn C. 2012. Dasar-Dasar Ekonometrika. (Raden Carlos Mangunsong, Trans). 2009. Jakarta: Penerbit Salemba Empat. (Original Work Diterbitkan Tahun 2009).

Gupta, S., De Mello, L., \& Sharan, R. (2001). Corruption and military spending. European Journal of Political Economy, 17(4), 749-777.

Henderson, J. V., \& Kuncoro, A. 2006. Does Local Democratization Reduce Corruption?. m\% Mimeo.

Hoa, Tran Van. 2010. Development And Corruption In Asia: A Substantive Econometric Analysis For Practical Policy Use. National Anti-Corruption Comission (NACC) Special Issue, Vol. 3, No. 2

Henisz, W. J. 2000. The Institutional Environment for Multinational Investment," Journal of Law, Economics and Organization, Oxford University Press, Vol. 16. No.2, October: 334-64.

Husted, B.W. 1999. Wealth, Culture, and Corruption. Journal of International Business Studies, Vol. 30, No. 2, June: 339-359

Jain, A. K., 2001. Corruption: A Review. Journal of Economic Surveys, Vol. 15, No.1, January: 71-121.

Kemendikbud. 2011. Pendidikan Anti Korupsi Untuk Perguruan Tinggi. Kemendikbud RI. Jakarta. 
Erlando, Studi Ekonomi Korupsi di Beberapa Kota di Indonesia.

Knack dan Keefer. 1995. Institutions And Economic Performance: Institutional Measures Cross-Country Tests Using Altern. Economics And Politcs, Vol.7, No.3, November: 207-227.

Kotera, G., Okada, K., dan Samreth, S. 2012. Government size, democracy, and corruption: An empirical investigation. Economic Modelling, 29(6), 2340-2348.

Kristiansen, S., dan Ramli, M. 2006. Buying an Income: The Market for Civil Service Positions in Indonesia. Contemporary Southeast Asia, Vol. 28, No. 2, 207-233.

Leite, C. dan Weidmann, J. 1999. Does Mother Nature Corrupt Natural Resources, Corruption, and Economic Growth. IMF Working Paper, No. 99/85, July: 1-30.

Litina, A. dan Palivos. T. 2015. Corruption, Tax Evasion And Social Values. Journal of Economic Behavior and Organization, October: 1-14.

Lui, Y. dan Feng, H. 2015. Tax Structure And Corruption: Cross-Country Evidence. Public Choice, Vol. 162, No. 1, January: 57-78.

Mandescu, Ionel. 2011. Tax Evasion And Corruption In The Development Of Romania. Bulletin of the Transilvania University of Braşov, Vol. 4, No. 53/2, 194-200.

Mauleny, Ariesy Tri. 2011. Urgensi RUU Pengadaan Barang dan Jasa Dalam Mendorong Pertumbuhan Ekonomi Melalui Good Governance. Pusat Pengkajian, Pengolahan Data dan Informasi (P3DI) Sekretariat Jenderal DPR Republik Indonesia. Jakarta.

Mauro, P. 1995. Corruption And Growth. The Quarterly Journal of Economics, Vol. 110, No. 3, August: 681-712.

Meon, Pierre.G. 2010. Is Corruption an Efficient Grease?. World Development, Vol. 38, No. 3, March: 244-259.

Nazir, F., Cheema, M. A., Zafar, M. I., \& Batool, Z. (2009). Socio-economic Impacts of Unemployment in Urban Faisalabad, Pakistan. Journal of Social Sciences, 18(3), 183188.

Nazir, Moh. 2003. Metode Penelitian Cetakan Kelima. Ghalia Indonesia. Jakarta

Neeleman J. dan Lewis G. 1999. Suicide Religion and Socioeconomic Conditions. An Ecological Study in 26 Countries, J Epidemiol Community HealthVol 1 No. 53, July: 204-210.

Nwabuzor, Augustine. 2005. Corruption and Development: New Initiatives in Economic Openness and Strengthened Rule of Law. Journal of Business Ethics, Vol.59, No. 1, June: $121-138$.

Nugroho, SBM. 2013. Korupsi dan faktor-faktor yang mempengaruhinya di Indonesia. Jurnal Ilmiah Dinamika Ekonomi Dan Bisnis. Vol. 1, No. 1. 
Paldam, Martin. 2002. The Cross-Country Pattern Of Corruption: Economics, Culture And The Seesaw Dynamics. European Journal of Political Economy, Vol. 18, No. 2, June: 215-240.

Pellegrini, L. dan Gerlagh, R. 2008. Causes Of Corruption: A Survey Of Cross-Country Analyses And Extended Results. Economics of Governance, Vol. 9, No. 3, July: 245263.

Picur, R. D. dan Belkaoui A. R. 2006. The Impact Of Bureaucracy, Corruption And Tax Compliance. Review of Accounting and Finance, Vol. 5, No. 2, 174-180.

Pradiptyo, R., Wirotomo, A., Hilman, R. M., \& Azzani, M. (2015). Naskah Akademik Prakarsa Bulaksumur Anti Korupsi. In makalah dalam Seminar Nasional Strategi Nasional Penanggulangan Korupsi yang diselenggarakan Universitas Gadjah Mada (Vol. 10)

Rahmani, T. dan Fallahi. S. 2009. Corruption, Democracy And Tax Compliance: CrossCountry Evidence, The Business \& Management Review, Vol. 2 No. 2, July: 221-230.

Rehman dan Naveed. 2007. Determinants Of Corruption And Its Relation To GDP (A Panel Study). Journal of Political Studies, Vol. XII, Winter: 27-59.

Rivayani. 2008. Corruption in Indonesia: Does Grease Hypothesis Hold ?. Discussion Paper on International Conference on Applied Economics.

Rock, M. T. dan Bonnett, Heidi. 2004. The Comparative Politics of Corruption: Accounting for the East Asian Paradox in Empirical Studies of Corruption, Growth and Investment. World Development Vol. 32, No. 6, 999-1017.

Rose, R. dan Mishler, W. 2010. Experience Versus Perception Of Corruption: Russia As A Test Case. Global Crime. Vol. 11, No. 2, May: 145-163.

Saha, S. dan Gounder, R. (2008) Causes Of Economic Corruption, Implication For India. 18th Annual Conference On Contemporary Issues In Development Economics, Jadavpur University, Kolkata.

Salih, M. A. R. 2013. The Determinants of Economic Corruption: A Probabilistic Approach. Advances in Management and Applied Economics, Vol. 3, No.3, May: 155-169.

Samimi, A. J., Abedini, M., \& Abdollahi, M. (2012). Corruption and inflation tax in selected developing countries. Middle-East Journal of Scientific Research, 11(3), 391-395.

Seligson, M. A. 2002. The Impact of Corruption on Regime Legitimacy: A Comparative Study of Four LatinAmerican Countries. The Journal of Politics, Vol. 64, No. 2, May: 408433. 
Erlando, Studi Ekonomi Korupsi di Beberapa Kota di Indonesia.

Sena, V. dan Martianova, N., 2008. Corruption And Foreign Direct Investment In Russian Regions. Unpublished Working Paper, Aston Business School, United Kingdom.

Sugiyono. 2012. Metode Penelitian Kuantitatif, Kualitatif, dan R\&D. Alfabeta. Bandung

Svensson, Jacob. 2005. Eight Questions about Corruption. Journal of Economic Perspectives, Vol. 19, No. 3, Summer: 19-42.

Tanzi, V. 1998. Corruption Around the World: Causes, Consequences, Scope, and Cures. Staff Papers - International Monetary Fund, Vol. 45, No.4: 559-594.

Tanzi, V. dan Davoodi, H.R. 2000. Corruption, Growth, and Public Finances. IMF Working Paper, No. 00/182, November: 1-27.

Ticky, N. L. 2010. The Causes Of Corruption: Explaining The High Levels Of Corruption In Developing Countries. Dissertation Presented to the Faculty of The University of Texas at Dallas in Partial Fulfillment of the Requirements for the Degree of Doctor Of Philosophy In Political Science, 1-134.

Tobin, J. 1958. Estimation of relationships for limited dependent variables. Econometrica: journal of the Econometric Society, 24-36.

Tosun, M. U. 2002. A Public Failure Product: Corruption and Efficient State, Ankara Chamber of Commerce Publication. Ankara.

Triesman, Daniel. 2000. The Causes Of Corruption: A Cross-National Study. Journal of Public Economics, Vol.76, No.3, June: 399-457.

Touati, K. 2014. Determinants of Economic Corruption in the Arab Countries: Dangers and Remedies. Journal of Economics Studies and Research. Vol. 1, No. 14. July: 1-15.

Wei, S. J. 2000. How Taxing is Corruption on International Investors ?. The Review of Economics and Statistics, Vol. 82, No 1, February: 1-11.

Wei S. J., dan Javorcik B. S. 2002. Corruption and Cross-Border Investment: Firm Level Evidence. William Davidson Institute Working Paper, No. 494. October:1-2. 